Pakistan Journal of Humanities and Social Sciences

October - December 2019, Volume 7, No. 4, Pages 343 - 356

\title{
Effect of Financial Risk, Privacy Risk and Product Risk on Online Shopping Behavior
}

\author{
Anam Bhatti ${ }^{1}$, Shahrin Saad ${ }^{2}$, Salimon Maruf Gbadebo ${ }^{3}$ \\ ${ }^{1} \mathrm{Ph} . \mathrm{D}$. Scholar Universiti Utara Malaysia \\ ${ }^{2}$ Senior Lecturer School of Business Management, Universiti Utara Malaysia \\ ${ }^{3}$ Visiting Lecturer School of Business Management, Universiti Utara Malaysia \\ Email: anambhatti1992@gmail.com
}

\begin{abstract}
The purpose of this study is to examine the direct influence of financial risk, privacy risk, and product risk on online shopping behavior. Existing study model developed on the base of theoretical background. In doing this, 280 questionnaires were examined using Smart PLSSEM. Convenience sampling used in this study. While the bulk of prior studies discovered a negative relationship between risks and online shopping behavior, this study also indicates that negative influence on online shopping behavior. The study offers additional insights into how risks can be decreased to increase the online shopping behavior that can be used to improve the plan while online shopping behavior can be enhanced. The current study reveals some important factors that affect the online shopping behavior of consumers and if we minimize these risks then significantly enhance the ratio of profits from online channels.
\end{abstract}

Keywords: Financial risk, Privacy risk, Product risk, Online shopping behavior

\section{Introduction}

Online shopping is growing rapidly all over the world. Internet continuously development strongly influence on worldwide marketing environment. The internet provides a new platform for organizations to develop their business through an online network. It became the third most popular activity after e-mail and web browsing. Online shopping facilitate people to buy anything any time with few clicks of the mouse, it provides 24/7 services (Izogo \& Jayawardhena, 2018). In developed countries well-developed infrastructure but in developing countries situation is different there it is growing but better than Pakistan (Khan \& Arshad, 2010). In Pakistan, online shopping started in the 2000's and still at the introductory stage. The internet has decrease cost for business and customers in searching, assessment, transaction, coverage, delivery and after sale services (Salam, Rao, \& Pegels, 2003). Online shopping is a visible threat to traditional channels of shopping because the 
internet provides a variety of products. Due to this reason, People moving towards digitalization day by day.

No doubt online shopping facilitate in various ways but along these advantages many risks connected with online shopping behavior and negatively aspects increasing frequently because of invisibility of products and intangibility (Mamman, Maidawa, \& Saleh, 2015). Many risks that affect consumer behavior such as financial risk, privacy risk, and product risk. In Pakistani context financial risk is a major issue during online shopping because of insecure transaction and low ratio of credit card that is less than $1 \%$, hacking passwords, insecure data all these issues leads to negativity in consumer behavior and consumer reluctant to buy (Nazir, Tayyab, Sajid, ur Rashid, \& Javed, 2012). Furthermore, people face issues regarding product such as product damages during delivery, wrong product deliver, delay in shipping, not accurate product and issues regarding to privacy such as personal data leakage and its misuse, and technological default leads to a negative influence on the online shopping behavior of consumers (Aijaz \& Butt, 2009; Qureshi, Fatima, \& Sarwar, 2014).

The purpose of this study is to determine the factors that influence online shopping behavior in Pakistan. There is a need to focus in this area in Pakistan because in Pakistan Govt. does not take an active part in the development of online shopping.

\section{Literature Review and Hypothesis Development}

\subsection{Online shopping behavior}

Online shopping behavior is buying goods and services from the internet. A few years ago people did not know the online buying and its advancement but now people well know about the internet and buying online. Internet plays very a significant role in searching, evaluating, comparing and buying products. Online shopping behavior is an individual perception and evaluation about the product in shopping that's results can be a good or bad way (Fatin Alia, 2016). Consumers considered important key for business success so, it is very important to study consumer behavior (Rahman, Islam, Esha, Sultana, \& Chakravorty, 2018). It is a time-saving process of shopping. Online shopping behavior consists of five elements e-store, logistics support, product features, technology features, websites, and home page demonstrator (Bashir, 2013). In addition, people trust online shopping sales and its convenience increasing day by day.

Online shopping behavior process is same as traditional shopping and consists five stages, consumer identifies the needed product, consumer start hunting information about that product, look alternatives then evaluate the product and purchase product that fulfills a need 
(Fazira, 2015). In contrast, consumer behavior in online shopping and traditional shopping due to different factors in the traditional way people can see and touch the product, but in online shopping, they just rely on advertisements. Consumer online shopping behavior depends on how, what, when and why. Many factors affect online shopping behavior in which financial risk, privacy risk, and product risk are most significant.

\subsection{Financial risk}

Financial risk refers to the loss in the monetary term associated with buying. It is a loss of money in a bad purchasing experience. Financial risk is the first major and big risk during buying online(Sinha \& Singh, 2017). In addition, it is also the strongest predictor of online shopping behavior. Financial risk play a major role in consumer decision making for buying online (Haider \& Nasir, 2016). Researchers reveal that financial risk is a money loss that possibly the fraud of credit card and discloses card information that's why people avoid buying online (Masoud, 2013; Sinha \& Singh, 2014). It is also considered that the product price is not the lowest in comparison (Egeln \& Joseph, 2012). Furthermore, the risk is problematic online buying process. Consumer faces financial risk in the early stage of shopping when they place an order. But, its level depends on the nature of the product, all products' risk level is different and there is no specific standard (L. F. Cunningham, Gerlach, Harper, \& Young, 2005).

This risk cogitate most important while buying online (Almousa, 2011, 2014; Bhatnagar, Misra, \& Rao, 2000; Candra \& Iahad, 2013; Crespo, del Bosque, \& de los Salmones Sánchez, 2009; M. S. Cunningham, 1967; Ingene \& Hughes, 1985; Jacoby \& Kaplan, 1972; Peter \& Ryan, 1976; Sharma \& Kurien, 2017; Stone \& Grønhaug, 1993; Zhang, Tan, Xu, \& Tan, 2012). Studies show the negative relationship between financial risk and online shopping behavior (Bhatnagar et al., 2000; Chang, Cheung, \& Lai, 2005; S. Forsythe, C. Liu, D. Shannon, \& L. C. Gardner, 2006; Haider \& Nasir, 2016). In future need more research in the relationship between this relation (Chaudary, Rehman, \& Nisar, 2014; Mamman et al., 2015).

H1: Financial risk has a significant negative relationship with online shopping behavior.

\subsection{Product risk}

Product risk is limited potential to examine the product. Online shopping is a risky way of shopping because in this way people cannot touch product they just rely on some graphics and ads. This risk becomes a hurdle in buying (Peter \& Tarpey Sr, 1975). It has a significant influence on consumer buying behavior that's why it is associated with consumer 
decisions (Forsythe \& Shi, 2003; Liu \& Forsythe, 2010). Product risk involves the loss of product standard means desired product not meet the expected product. Furthermore, this risk is related to customer satisfaction if the product cannot satisfy customer expectation then the loss of money and product as well. Some retailer does not have after sale services that also affect the frequency of purchasing online. This risk is considered a very serious risk and its negative experience and loss of confidence and repute.

Some issues linked with product risk such limited stock of product, limited information of the product, deliver a wrong product, delay product, product not same with picture (Saprikis, Chouliara, \& Vlachopoulou, 2010). Moreover, prior studies reveal the significant negative relationship between product risk and online shopping behavior (Ariff, Sylvester, Zakuan, Ismail, \& Ali, 2014; Chakraborty, 2016; S. M. Forsythe, C. Liu, D. Shannon, \& L. C. Gardner, 2006; Haider \& Nasir, 2016; Ko, Jung, Kim, \& Shim, 2004; Masoud, 2013; Shahzad, 2015). No doubt there are various studies on this topic but limited in developing countries so, still need more research in future (Masoud, 2013; Rizwan, Umair, Bilal, Akhtar, \& Bhatti, 2014; Shahzad, 2015).

H2: Product risk has a significant negative relationship with online shopping behavior.

\subsection{Privacy risk}

In globalization with the growth of online shopping privacy risk also increases. Privacy risk refers to possible loss of personal information, in other words, use without approval (Crespo et al., 2009; Featherman \& Pavlou, 2003; Stone \& Grønhaug, 1993). Privacy risk is a very important risk considered in online shopping behavior. Furthermore, it is a big challenge for customers. In addition during online shopping, customers must provide some information about their personal credit card, name, address, etc, and unethically use of this information due to these matters consumers reluctant to buy online. Privacy risk increases uncertainty and a significant influence on the frequency of online shopping behavior (Forsythe \& Shi, 2003).

In addition, people react diversely for privacy risk due to different reasons such as in different culture people react different, external situations like past experience. Privacy risk influence on online shopping behavior is not clear and still interesting for the researcher so, in this study, take privacy risk with online shopping behavior. Almost $8 \%$ people in the world who left online shopping because of privacy risk and 54\% people in the world who never try to buy online because they consider that online shopping is a dangerous way to buy something. Prior studies show that significant negative influence of privacy risk on online 
shopping behavior (Masoud, 2013; S.-u. Rehman, 2018; Tanadi, Samadi, \& Gharleghi, 2015; Zhang et al., 2012).

H3: Privacy risk has a significant negative relationship with online shopping behavior.

Figure 1: Theoretical Framework

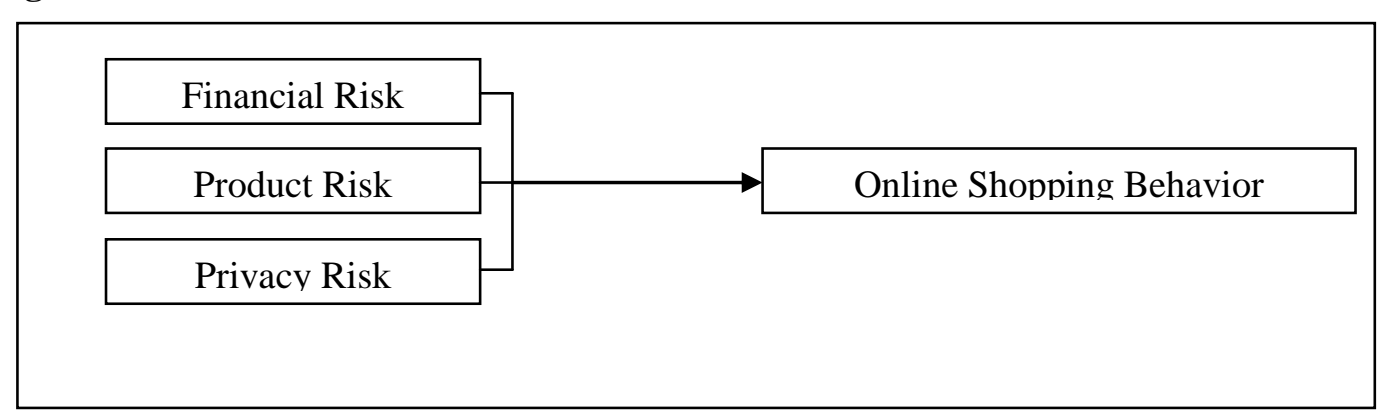

\section{Research Methodology}

The research design is a map that guides us on how to get answers to the research questions (Rehman, Mohamed, \& Ayoup, 2019). It is a very important part of any research because it is very necessary to follow a plan to meet research objectives (Rehman et al., 2019). There are different techniques but in this study quantitative approach use, a deductive study in nature, this study is a cross-sectional study and a self-administrated questionnaire was designed.

In the current study, the framework consists of four variables, three independent variables financial risk, product risk, privacy risk, and one dependent variable online shopping behavior. These variables measured by various items that are adopted by different studies. In this study 5 Likert scale was used and study is quantitative in nature. Financial risk and product risk consists of 5 items (Masoud, 2013). Privacy risk consists of 4 items (Dinev $\&$ Hart, 2005). Online shopping behavior consists of 17 items (Moshrefjavadi, Dolatabadi, Nourbakhsh, Poursaeedi, \& Asadollahi, 2012).

\subsection{Data collection}

Data was collected from different universities of Pakistan by using convenience sampling because it also saves time and money. According to Roscoe (1975), minimum respondents should be 30 and 500 should be maximum for getting good results. If the sample size will increase than 500 then the results will be not good. So, in this study sample size 280 and 300 questionnaires were distributed among students who buy online and receive 280 by extracting missing values. 114 were male and 166 were female. 


\subsection{Demographic profile}

As mention in Table 1 total respondents were 280 in which 114 (40.7\%) were male and $166(59.3 \%)$ were female. In which $9.6 \%$ were below 20 age, $74.6 \%$ were 21 to 30 years, $13.9 \%$ were 30 to 40 years, and $1.8 \%$ were more than 40 . As regarding qualification $5.0 \%$ were Intermediate students, $32.1 \%$ were Bachelor Degree, 61.4\% Master Degree, .7 were Ph.D. and .7 were others.

Table 1: Demographic profile

\begin{tabular}{|c|c|c|c|}
\hline Construct & Category & Number of cases & Percentage \\
\hline Gender & Male & 114 & 40.7 \\
\hline & Female & 166 & 59.3 \\
\hline \multirow{4}{*}{ Age } & Less than 20 years & 27 & 9.6 \\
& 21 to 30 years & 209 & 74.6 \\
& 30 to 40 years & 39 & 13.9 \\
& More than 40 & 5 & 1.8 \\
\hline \multirow{5}{*}{ Qualification } & Intermediate & 14 & 5.0 \\
& Bachelor Degree & 90 & 32.1 \\
& Master Degree & 2 & 61.4 \\
& Ph.D. & 2 & .7 \\
\hline
\end{tabular}

\subsection{Statistical analysis results}

In the current study for analyzing our theoretical model, we use (PLS-SEM) Partial Least Square technique. It is proved that this technique is best to handle simple and complex both type of models and it also works on un-normal data so, it considers good than other techniques like covariance- based technique (Bamgbade, Kamaruddeen, \& Nawi, 2015; Hair Jr, Hult, Ringle, \& Sarstedt, 2014). Furthermore, in this study, we are using measurement and structural model by using PLS-SEM technique.

\subsection{Measurement Model}

To evaluate measurement model there is a need to calculate three major validity analysis such as content, discriminant, and convergent (Hair, Ringle, \& Sarstedt, 2013). In the current study, three conditions fulfill and meet required criteria. As shown in Fig 2 and Table 1. Table 2 demonstrates that the required criteria for CR and AVE meet that was CR values must be higher than 0.60, and AVE values higher than 0.50 as recommended (Hair et al., 2013). According to Nunnally (1978), the value of Cronbach's alpha must be 0.70 or higher than 0.70. Table 3 shows that Heterotrait-Monotrait Ratio (HTMT) meet the threshold value (less than 0.85) as suggested (Hair et al., 2013). 
Pakistan Journal of Humanities and Social Sciences, 7(4), 2019

Figure 2: Measurement Model

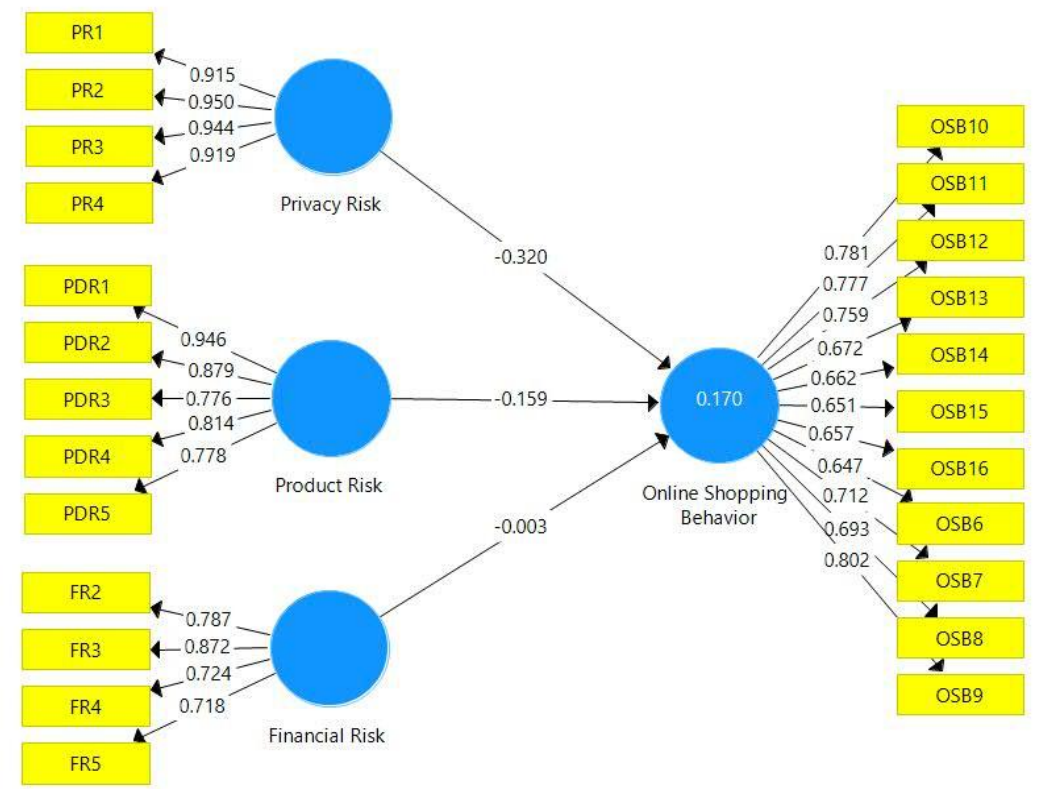

Table 2: $\quad$ Factor Loadings, Average Variance Extracted (AVE), and Composite Reliability (CR)

\begin{tabular}{|c|c|c|c|c|c|c|c|}
\hline Variables & Items & Factor Loading & AVE & $\mathbf{C R}$ & $\begin{array}{c}\text { Cronbach } \\
\text { Alpha }\end{array}$ & $\mathbf{R 2}$ & Rho_A \\
\hline $\begin{array}{l}\text { Privacy } \\
\text { Risk }\end{array}$ & $\begin{array}{l}\text { PR1 } \\
\text { PR2 } \\
\text { PR3 } \\
\text { PR4 } \\
\end{array}$ & $\begin{array}{l}0.915 \\
0.950 \\
0.944 \\
0.919 \\
\end{array}$ & 0.869 & 0.964 & 0.950 & & 0.963 \\
\hline $\begin{array}{l}\text { Product } \\
\text { Risk }\end{array}$ & $\begin{array}{l}\text { PDR1 } \\
\text { PDR2 } \\
\text { PDR3 } \\
\text { PDR4 } \\
\text { PDR5 }\end{array}$ & $\begin{array}{l}0.946 \\
0.879 \\
0.776 \\
0.814 \\
0.778\end{array}$ & 0.707 & 0.923 & 0.895 & & 0.905 \\
\hline $\begin{array}{c}\text { Financial } \\
\text { Risk }\end{array}$ & $\begin{array}{l}\text { FR2 } \\
\text { FR3 } \\
\text { FR4 } \\
\text { FR5 }\end{array}$ & $\begin{array}{l}0.787 \\
0.872 \\
0.724 \\
0.718 \\
\end{array}$ & 0.605 & 0.859 & 0.812 & & 0.805 \\
\hline $\begin{array}{c}\text { Online } \\
\text { Shopping } \\
\text { Behavior }\end{array}$ & $\begin{array}{c}\text { OSB10 } \\
\text { OSB11 } \\
\text { OSB12 } \\
\text { OSB13 } \\
\text { OSB14 } \\
\text { OSB15 } \\
\text { OSB16 } \\
\text { OSB6 } \\
\text { OSB7 } \\
\text { OSB8 } \\
\text { OSB9 }\end{array}$ & $\begin{array}{l}0.781 \\
0.777 \\
0.759 \\
0.672 \\
0.662 \\
0.651 \\
0.657 \\
0.647 \\
0.712 \\
0.693 \\
0.802\end{array}$ & 0.507 & 0.918 & 0.902 & 0.170 & 0.906 \\
\hline
\end{tabular}


Table 3: Heterotrait-Monotrait Ratio (HTMT)

\begin{tabular}{|l|l|l|l|l|}
\hline Variable & FR & OSB & PR & PDR \\
\hline FR & & & & \\
\hline OSB & 0.118 & & & \\
\hline PR & 0.260 & 0.408 & & \\
\hline PDR & 0.153 & 0.318 & 0.439 & \\
\hline
\end{tabular}

Table 4: Cross Loadings

\begin{tabular}{|l|l|l|l|l|}
\hline Items & FR & OSB & PDR & PR \\
\hline FR2 & $\mathbf{0 . 7 8 7}$ & -0.020 & 0.074 & 0.175 \\
FR3 & $\mathbf{0 . 8 7 2}$ & -0.113 & 0.168 & 0.305 \\
FR4 & $\mathbf{0 . 7 2 4}$ & -0.019 & 0.137 & 0.060 \\
FR5 & $\mathbf{0 . 7 1 8}$ & -0.093 & -0.005 & 0.187 \\
\hline OSB10 & -0.089 & $\mathbf{0 . 7 8 1}$ & -0.196 & -0.310 \\
OSB11 & -0.044 & $\mathbf{0 . 7 7 7}$ & -0.203 & -0.279 \\
OSB12 & -0.078 & $\mathbf{0 . 7 5 9}$ & -0.215 & -0.260 \\
OSB13 & -0.001 & $\mathbf{0 . 6 7 2}$ & -0.192 & -0.244 \\
OSB14 & -0.064 & $\mathbf{0 . 6 6 2}$ & -0.260 & -0.314 \\
OSB15 & -0.083 & $\mathbf{0 . 6 5 1}$ & -0.236 & -0.237 \\
OSB16 & -0.011 & $\mathbf{0 . 6 5 7}$ & -0.171 & -0.202 \\
OSB6 & -0.127 & $\mathbf{0 . 6 4 7}$ & -0.133 & -0.276 \\
OSB7 & -0.150 & $\mathbf{0 . 7 1 2}$ & -0.155 & -0.319 \\
OSB8 & -0.104 & $\mathbf{0 . 6 9 3}$ & -0.207 & -0.229 \\
OSB9 & -0.116 & $\mathbf{0 . 8 0 2}$ & -0.272 & -0.310 \\
\hline PDR1 & 0.113 & -0.284 & $\mathbf{0 . 9 4 6}$ & 0.394 \\
PDR2 & 0.096 & -0.245 & $\mathbf{0 . 8 7 9}$ & 0.361 \\
PDR3 & 0.055 & -0.238 & $\mathbf{0 . 7 7 6}$ & 0.347 \\
PDR4 & 0.081 & -0.230 & $\mathbf{0 . 8 1 4}$ & 0.292 \\
PDR5 & 0.144 & -0214 & $\mathbf{0 . 7 7 8}$ & 0.308 \\
\hline PR1 & 0.264 & -0.309 & 0.364 & $\mathbf{0 . 9 1 5}$ \\
PR2 & 0.246 & -0.414 & 0.386 & $\mathbf{0 . 9 5 0}$ \\
PR3 & 0.300 & -0.369 & 0.413 & $\mathbf{0 . 9 4 4}$ \\
PR4 & 0.272 & -0.330 & 0.350 & $\mathbf{0 . 9 1 9}$ \\
\hline
\end{tabular}

Table 4 shows that factor loading of the respective construct must be higher than other variables in the same row and column as recommended (Hair et al., 2013).

\subsection{Assessment of Structural Model}

We discuss in this paragraph direct hypothesis between financial risk, product risk, privacy risk (independent variable) and online shopping behavior (dependent variable). Significant values of loadings and path-coefficient authors recommended that execute bootstrap with 5000 subsamples (Hair Jr, Hult, Ringle, \& Sarstedt, 2016). Table 4 shows the findings of the structural model. 
Figure 3 Structural Model

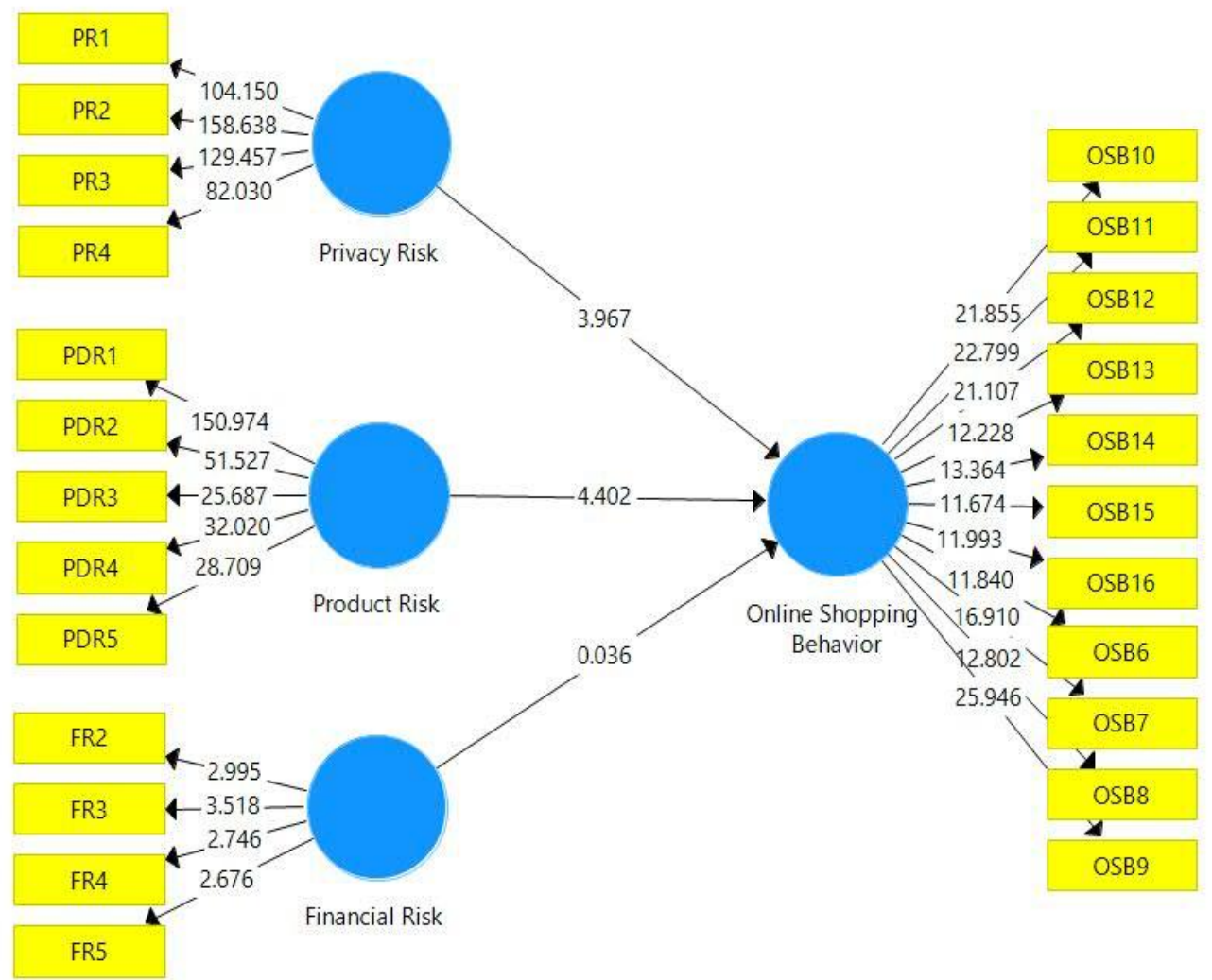

Table 5: Direct relationships

\begin{tabular}{|c|c|c|c|c|c|}
\hline Hypotheses & Paths & $\begin{array}{c}\text { Path } \\
\text { co-efficient }\end{array}$ & T-values & P-values & Results \\
\hline $\mathrm{H}_{1}$ & FR --> OSB & -0.003 & 0.036 & 0.971 & Not-Supported \\
\hline $\mathrm{H}_{2}$ & PR --> OSB & -0.320 & 3.967 & 0.000 & Supported \\
\hline $\mathrm{H}_{3}$ & PDR --> OSB & -0.159 & 4.402 & 0.000 & Supported \\
\hline
\end{tabular}

\subsection{Results}

Table 5 demonstrates, this study has three hypotheses and only two hypotheses supported and remaining one not supported. For example, financial risk (FR) has no relationship with online shopping behavior as $(\beta=-0.003$, $t$-value $=0.036$, and $p$-value $>0.05)$ and $\mathrm{H}_{1}$ not supported. Moreover, privacy risk (PR) has a significant negative influence on online shopping behavior as $(\beta=-0.320$, $\mathrm{t}$-value $=3.967$, and $\mathrm{p}$-value $<0.05)$ and $\mathrm{H}_{2}$ supported. Meanwhile, product risk (PDR) has a significant and decreasing influence on online shopping behavior as $(\beta=-0.159$, $\mathrm{t}$-value $=4.402$, and $\mathrm{p}$-value $<0.05)$ and $\mathrm{H}_{3}$ supported. 


\section{Discussion and Conclusion}

The aim of the current study is to examine the influence of financial risk, privacy risk, and product risk on online shopping behavior in Pakistan. The nature of this study was descriptive and quantitative. Results revealed that financial risk has an insignificant influence on online shopping behavior, and $\mathrm{H}_{1}$ not supported. The findings of this study are in line with (S. u. Rehman, 2018). The results show that in the context of Pakistan the decision to purchase goods online not affected due to financial risk and consumer purchase goods even they face financial risk. Moreover, privacy risk has a significant and negative influence on online shopping behavior, and $\mathrm{H}_{2}$ accepted. The results are similar to prior studies (Masoud, 2013; S. u. Rehman, 2018). This shows that privacy risk significantly matters in online shopping behavior and consumers avoid or reduce online shopping in the presence of privacy risk. Product risk has a significant and negative influence on online shopping behavior, and $\mathrm{H}_{3}$ supported. The results are in line with some prior studies (Haider \& Nasir, 2016; Masoud, 2013). This demonstrates that consumers give importance to product risk at the time of purchasing goods online. Product risk changes their decision and they might go to purchase goods physically or traditionally or reduce online shopping. Therefore, this study concludes that product risk and privacy risk significantly decrease online shopping behaviour. While financial risk not matters in online shopping.

\subsection{Theoretical implication}

Financial risk, product risk, privacy risk, and online shopping behavior are the variables of the current study. However the majority of studies on these variables but in diverse contents, the exclusivity of this study is that these variables are deliberated from Ecommerce viewpoints which utmost of the earlier studies have largely unnoticed and ignored. Therefore designates that the framework of this study will carry on to be a point of reference for upcoming academicians and researchers who may be fascinated in examining online shopping behavior.

\subsection{Practical Implication}

A lot of practical implication can be drained from the current study as the outcomes of the current study would carry on guiding online retailers, online suppliers, marketers, and planning makers. The current study reveals some important factors that affect the online shopping behavior of consumers and if we minimize these risks then significantly enhance the ratio of profits from online channels. The practical implication of risks on online shopping, it is very important for online retailers, the online service provider to coming up stages that are 
Pakistan Journal of Humanities and Social Sciences, 7(4), 2019

deemed secure and safe. Practically retailers focus on these risks, this will ensure that a secure online network makes online shoppers to enjoy a high quality of interactions and benefits of online shopping.

\section{Limitations and Suggestions}

This study is the same as past researches have some limitations that must be deliberate when deducing its results. This research conducted in Pakistan, a developing country and amongst online shoppers. This poses a limitation due to the distinctiveness of the context level of using technology in Pakistan. Thus, it is highly suggested that in future researcher should conduct research on a similar topic in other developed and developing countries and test the objectives and results of this study. Another limitation of this study is that the current study focus on online shoppers in this instance, the suggestion for upcoming researchers conducts comparative studies among online shoppers and non-online shoppers.

As mention above that most research has done in developed countries, and in developing countries, less attention has been paid on online shopping behavior so, there is need more study the area in developed as well as developing countries with different perceived risks. In the current study test direct relationship between risks and online shopping behavior in the future, there is a need to add moderator between these relations.

\section{References}

Aijaz, H., \& Butt, F. S. (2009). BARRIERS IN THE DEVELOPMENT OF ELECTRONIC COMMERCE: A STUDY OF PAKISTANI ENVIORNMENT.

Almousa, M. (2011). Perceived Risk in Apparel Online Shopping: A Multi Dimensional Perspective. Canadian Social Science, 7(2), 23.

Almousa, M. (2014). The influence of risk perception in online purchasing behavior: examination of an early-stage online market. International Review of Management and Business Research, 3(2), 779.

Ariff, M. S. M., Sylvester, M., Zakuan, N., Ismail, K., \& Ali, K. M. (2014). Consumer Perceived Risk, Attitude and Online Shopping Behaviour; Empirical Evidence from Malaysia. Paper presented at the IOP Conference Series: Materials Science and Engineering.

Bamgbade, J. A., Kamaruddeen, A. M., \& Nawi, M. (2015). Factors influencing sustainable construction among construction firms in Malaysia: A preliminary study using PLSSEM. Revista Tecnica De La Facultad De Ingenieria Universidad Del Zulia (Technical Journal of the Faculty of Engineering, TJFE), 38(3), 132-142.

Bashir, A. (2013). Consumer Behavior towards online shopping of electronics in Pakistan.

Bhatnagar, A., Misra, S., \& Rao, H. R. (2000). On risk, convenience, and Internet shopping behavior. Communications of the ACM, 43(11), 98-105.

Candra, R. M., \& Iahad, N. A. (2013). Analysis of Consumer Risk Perception on Online Auction Features. Universiti Teknologi Malaysia. 
Chakraborty, D. (2016). Factors Affecting Consumer Purchase Decision towards Online Shopping: a Study Conducted in Gangtok, Sikkim. Adarsh Business Review, 3(1), 1118.

Chang, M. K., Cheung, W., \& Lai, V. S. (2005). Literature derived reference models for the adoption of online shopping. Information \& Management, 42(4), 543-559.

Chaudary, S., Rehman, M. A., \& Nisar, S. (2014). Factors influencing the acceptance of online shopping in pakistan.

Crespo, A. H., del Bosque, I. R., \& de los Salmones Sánchez, M. G. (2009). The influence of perceived risk on Internet shopping behavior: a multidimensional perspective. Journal of Risk Research, 12(2), 259-277.

Cunningham, L. F., Gerlach, J. H., Harper, M. D., \& Young, C. E. (2005). Perceived risk and the consumer buying process: Internet airline reservations. International Journal of Service Industry Management, 16(4), 357-372.

Cunningham, M. S. (1967). The major dimensions of perceived risk. Risk taking and information handling in consumer behavior.

Dinev, T., \& Hart, P. (2005). Internet privacy concerns and social awareness as determinants of intention to transact. International Journal of Electronic Commerce, 10(2), 7-29.

Egeln, L. S., \& Joseph, J. A. (2012). Shopping cart abandonment in online shopping. Atlantic Marketing Journal, 1(1), 1.

Fatin Alia, S. (2016). Understanding student's online shopping behaviour: A study among undergraduate students in UUM. Universiti Utara Malaysia.

Fazira, A. T. (2015). Factors influencing online shopping behaviors of Facebook users among undergraduate students in UUM, Sintok, Kedah. Universiti Utara Malaysia.

Featherman, M. S., \& Pavlou, P. A. (2003). Predicting e-services adoption: a perceived risk facets perspective. International journal of human-computer studies, 59(4), 451-474.

Forsythe, S., Liu, C., Shannon, D., \& Gardner, L. C. (2006). Development of a scale to measure the perceived benefits and risks of online shopping. Journal of interactive marketing, 20(2), 55-75.

Forsythe, S. M., Liu, C., Shannon, D., \& Gardner, L. C. (2006). Development of a scale to measure the perceived benefits and risks of online shopping. Journal of interactive marketing, 20(2), 55-75.

Forsythe, S. M., \& Shi, B. (2003). Consumer patronage and risk perceptions in Internet shopping. Journal of Business research, 56(11), 867-875.

Haider, A., \& Nasir, N. (2016). Factors Affecting Online Shopping Behavior of Consumers in Lahore, Pakistan.

Hair, J. F., Ringle, C. M., \& Sarstedt, M. (2013). Partial least squares structural equation modeling: Rigorous applications, better results and higher acceptance.

Hair Jr, J. F., Hult, G. T. M., Ringle, C., \& Sarstedt, M. (2014). A primer on partial least squares structural equation modeling (PLS-SEM): Sage Publications.

Hair Jr, J. F., Hult, G. T. M., Ringle, C., \& Sarstedt, M. (2016). A primer on partial least squares structural equation modeling (PLS-SEM): Sage Publications.

Ingene, C. A., \& Hughes, M. (1985). Risk management by consumers. Research in consumer behavior, 1, 103-158.

Izogo, E. E., \& Jayawardhena, C. (2018). Online shopping experience in an emerging eretailing market. Journal of Research in Interactive Marketing, 12(2), 193-214.

Jacoby, J., \& Kaplan, L. B. (1972). The components of perceived risk. ACR Special Volumes.

Khan, S. H., \& Arshad, M. Z. (2010). Why E-Commerce Remains Unsuccessful in Pakistan?

Ko, H., Jung, J., Kim, J., \& Shim, S. W. (2004). Cross-cultural differences in perceived risk of online shopping. Journal of Interactive Advertising, 4(2), 20-29. 
Pakistan Journal of Humanities and Social Sciences, 7(4), 2019

Liu, C., \& Forsythe, S. (2010). Post-adoption online shopping continuance. International Journal of Retail \& Distribution Management, 38(2), 97-114.

Mamman, H., Maidawa, M., \& Saleh, M. (2015). Effects of Perceived Risk on Online Shopping.

Masoud, E. Y. (2013). The effect of perceived risk on online shopping in Jordan. European Journal of Business and Management, 5(6), 76-87.

Moshrefjavadi, M. H., Dolatabadi, H. R., Nourbakhsh, M., Poursaeedi, A., \& Asadollahi, A. (2012). An analysis of factors affecting on online shopping behavior of consumers. International Journal of Marketing Studies, 4(5), 81.

Nazir, S., Tayyab, A., Sajid, A., ur Rashid, H., \& Javed, I. (2012). How online shopping is affecting consumers buying behavior in Pakistan? International Journal of Computer Science Issues (IJCSI), 9(3), 486.

Nunnally, J. (1978). Psychometric Theory (2nd Edit.) McGraw-Hill. Hillsdale, NJ.

Peter, J. P., \& Ryan, M. J. (1976). An investigation of perceived risk at the brand level. Journal of marketing research, 184-188.

Peter, J. P., \& Tarpey Sr, L. X. (1975). A comparative analysis of three consumer decision strategies. Journal of consumer research, 2(1), 29-37.

Qureshi, H. A., Fatima, R., \& Sarwar, A. (2014). BARRIERS TO ADOPTION OF ONLINE SHOPPING IN PAKISTAN. Science International, 26(3).

Rahman, M. A., Islam, M. A., Esha, B. H., Sultana, N., \& Chakravorty, S. (2018). Consumer buying behavior towards online shopping: An empirical study on Dhaka city, Bangladesh. Cogent Business \& Management, 5(1), 1-22.

Rehman, S.-u. (2018). Impact of Financial Risk, Privacy Risk, Convenience, and Trust on Online Shopping With Mediating Role of Consumer Purchase Intention in Pakistan. International Journal of Academic Multidisciplinary Research (IJAMR), 2(8), 27-34.

Rehman, S.-u., Mohamed, R., \& Ayoup, H. (2019). The mediating role of organizational capabilities between organizational performance and its determinants. Journal of Global Entrepreneurship Research, 9(1), 30. doi: 10.1186/s40497-019-0155-5

Rehman, S. u. (2018). Impact of Financial Risk, Privacy Risk, Convenience, and Trust on Online Shopping With Mediating Role of Consumer Purchase Intention

International journal of Academic Multidisciplinary Research (IJAMR), 2(8), 27-34.

Rizwan, M., Umair, S. M., Bilal, H. M., Akhtar, M., \& Bhatti, M. S. (2014). Determinants of customer intentions for online shopping: A Study from Pakistan. Journal of Sociological Research, 5(1), 248-272.

Roscoe, J. T. (1975). Fundamental research statistics for the behavioral sciences [by] John T. Roscoe.

Salam, A. F., Rao, H. R., \& Pegels, C. C. (2003). Consumer-perceived risk in e-commerce transactions. Communications of the ACM, 46(12), 325-331.

Saprikis, V., Chouliara, A., \& Vlachopoulou, M. (2010). Perceptions towards online shopping: Analyzing the Greek university students' attitude. Communications of the IBIMA.

Shahzad, H. (2015). Online Shopping Behavior.

Sharma, J. K., \& Kurien, D. (2017). Perceived Risk in E-Commerce: A Demographic Perspective. NMIMS Management Review, 34(1), 31-57.

Sinha, P., \& Singh, S. (2014). Determinants of consumers' perceived risk in online shopping: A study. Indian Journal of Marketing, 44(1), 22-32.

Sinha, P., \& Singh, S. (2017). Comparing risks and benefits for the value enhancement of online purchases. Gadjah Mada International Journal of Business, 19(3), 307. 
Stone, R. N., \& Grønhaug, K. (1993). Perceived risk: Further considerations for the marketing discipline. European Journal of marketing, 27(3), 39-50.

Tanadi, T., Samadi, B., \& Gharleghi, B. (2015). The impact of perceived risks and perceived benefits to improve an online intention among generation-Y in Malaysia. Asian Social Science, 11(26), 226.

Zhang, L., Tan, W., Xu, Y., \& Tan, G. (2012). Dimensions of consumers' perceived risk and their influences on online consumers' purchasing behavior. Communications in Information Science and Management Engineering, 2(7). 